\title{
Preface
}

\section{GOOD READING ABOUT THE FIFTIETH STATE}

"What should I read about Hawaii?"

More than twenty thousand bound volumes are to be found in the Hawaiian Collection of the University of Hawaii Library. Many people are amazed to learn that such a deluge of words has been printed concerning a North Pacific archipelago. To answer this question, I have spent more than thirty years browsing in that outstanding collection, seeking volumes that have literary merit-that, in other words, would be enjoyed by any reader regardless of the island setting.

For historical reasons, Hawaii has a literary heritage more varied than that of most other American states. It derives from a group of subtropical islands far from any continent, settled more than a millennium ago by Polynesian canoevoyagers bringing with them a skilled culture developed under severe South Sea conditions. After centuries of civil conflict, one outstanding ruler emerged, unifying the islands through the aid of European wanderers who had come there after the men of Captain James Cook's expedition had revealed the existence of the archipelago to the outside world. The Kamehameha dynasty, often, after 1819, with the advice of American missionaries, was replaced in 1872 by elected monarchs. Geographical, economic, and educational influences led increasingly to an American hegemony over the islands, and several years after a revolution led by proannexation residents, the American flag first flew over the group in 1898. The assimilation of immigrants from half a dozen Asian and Pacific countries finally resulted in a modern community that is a showcase of American democracy in 
Oceania. Hawaii became the fiftieth state of the Union in 1959.

The literature of Hawaii embodies the best writings about this fascinating region, the books that evoke the flavor and allure of the "Paradise of the Pacific." Until now, although several million visitors come annually to view the varied wonders of the islands, the need for an introduction to this branch of literature in English has not been met. With twenty thousand books to choose from, discernment is certainly required. A selective, annotated guide through this mass of printed material is herein supplied, in the hope of aiding the visitor, the student, the teacher, the collector, the librarian, and-most of all-the informed reader who enjoys losing himself in tales of demigods and ghosts, voyagers by canoe or frigate, castaways, beachcombers, seekers of the "noble savage," escapists from over-civilized areas, missionaries, sandalwood traders, deserters and convicts, whalemen, brown-skinned Polynesian monarchs, scientists and travelers, sun-seeking artists and poets, yachtsmen, and visiting authors of world renown.

What types of literature are prominent? The customary history of American writing, for example, begins with oral records of the aboriginal beliefs and customs, logs of sea explorers, regional histories, memoirs, journals and diaries, missionary reports, travels, and even sermons. These are the types that one generally finds in any study of a frontier region. The works may, also, have modest claims to literary merit and charm, are often fresh and interesting, and give valuable insights into the places, times, and events involved; further, they may provide background and other material for later, more creative writers. It is not surprising that the types of authorship found early in the history of Hawaii, another frontier region, should follow this pattern.

The native literature of Hawaii, like that of the rest of the Polynesian Triangle, was not written, but was handed down by word of mouth-often through many generations of trained bards and reciters of genealogies. Oratory was a great Polynesian art, and the speaker stirred his listeners with sparkling metaphors and allusions to classic stories. The 
court of a nobleman always included a poet whose duty it was to compose chants and to recite genealogies. There was also a class of strolling minstrels who entertained the villagers with folk tales and stories of heroes. A sport of the nobility, in which lives were often at stake, was the literary tournament; the contestants rivaled each other in composing songs and in riddling, punning, reciting the names of persons and places, and competing in other tests of wit and word play. The hula was not only a dance but a religious art that took the place of our concert hall and lecture room, our opera and theater. Hence the collected lore of Hawaii provides a fertile source of knowledge about the history, traditions, customs, arts, and religious ideals of these early people. The tone of the literature is primarily aristocratic, however, and the common folk merely serve to set off the exploits of their gods, heroes, and chiefs.

Hawaiian literary style is marked by exaggeration, humor, antithesis, and the use of revealing details in characterization. Names of persons and regions are repeated again and again: such catalogs were recited with great enjoyment. (Later, when the missionaries came, they found that their pupils liked best to memorize those parts of the Bible that list the "begats.") Both prose and poetry are filled with simile and symbolism, drawn mainly from the various aspects of nature-rain, flowers, forests, the moon.

The first written records of native literature come from James Cook and his crew members-including several Polynesians from Tahiti, who found the Hawaiian language quite similar to their own. No standard scheme of writing Hawaiian speech in a roman alphabet was used until the early 1820 s, when a group of Protestant missionaries limited the letters to seventeen, which in 1826 were further reduced to twelve. The five vowels were given the Italian pronounciation; these, together with seven consonants- $h, k, l, m, n, p$, and $w$-enabled any Hawaiian word to be written. It was then possible not only to begin translating the Bible and other worthy works into Hawaiian but to permit the Hawaiian people to write down their stories and recollections in their own language, to be translated later by others. Wide 
shelves of books in Hawaiian may be found in the libraries of the islands, and language courses are given that enable students today to enjoy this body of aboriginal writing.

My selection of books to review begins, then, with works by persons of Hawaiian blood, in English translation. Translators of such caliber as Martha Beckwith, Nathaniel B. Emerson, William Hyde Rice, Mary Kawena Pukui, Katharine Luomala, Samuel H. Elbert, and Alfons L. Korn have given us volumes that re-create the wealth of myth, legend, and song transmitted through the ages on Polynesian islands. Native authors such as David Malo, Samuel M. Kamakau, S. N. Haleole, Kepelino Keauokalani, and John Ii are well represented in translation, partly as a result of the movement that started among the teachers of history at the mission high school at Lahainaluna, Maui, in the latter 1830s.

The writing of the history of the Hawaiian Islands, in fact, began before the modern reader might imagine that there was very much history to record. The Reverend Sheldon Dibble published at Lahainaluna in 1843 his History of the Sandwich Islands, incorporating much of the material gathered orally by his students among their village elders. The first solid history by a professional author (who was also the first to publish a novel based on the lore of the islands) was written by James J. Jarves, and also appeared in 1843, along with a companion volume of travel essays. A history of Hawaii by one who had never visited the islands was written in London by Manley Hopkins and appeared in 1862. The practice of documentary history culminated in 1967 with The Hawaiian Kingdom, the monumental three-volume work by Ralph S. Kuykendall. Kuykendall also wrote a one-volume history of the islands, as have contemporary writers Gavan Daws, A. Grove Day, Gerrit P. Judd, W. Storrs Lee, and Edward Joesting. Day (in collaboration with Carl Stroven), Judd, and Lee have also compiled anthologies of writings in English about Hawaii.

The historical dividing line in Hawaiian history is, of course, the discovery of the group in 1778 by Captain James Cook, R.N., during his third Pacific voyage. Castaways from European or Asian vessels may have reached Hawaiian 
shores in previous times, but until Cook's two ships sighted the northwestern three islands, no knowledge of the interesting culture of these Polynesian settlers in the North Pacific had reached beyond the region. The journals of Cook and his men-who were often skillful in describing what they saw-is the source at which students of Hawaiian civilization must start; for changes began to affect that fragile life-style even on the two nights when twenty seamen were stormbound on the islet of Niihau in January 1778. The accounts by Cook, James King, David Samwell, and others of the voyagers are the primary sources for studies of "ancient" Hawaiian customs, beliefs, and language; changes were reported even as soon as Nathaniel Portlock, George Dixon, and George Vancouver (all of whom had been in Cook's crews) led trading voyages to Hawaii a few years later.

Accounts by such traders-along with those of sea wanderers like the indomitable Archibald Campbell, the semi-pirate Peter Corney, and Captain Amasa Delano-supplement the reading of more formal historians. Among the explorers from other nations who hoped to vie with Cook in Pacific empire-building, Otto von Kotzebue, son of a celebrated German dramatist, is the most engrossing storyteller. Kotzebue was an officer on three visits by Russian ships. The Russian filibustering efforts around 1815 , which planted the Czar's flag over the island of Kauai, inspired a historical novel by Darwin Teilhet.

The Protestant mission program centered in Boston, aiming at Christianizing the Hawaiian Islands, has produced a voluminous quantity of writing, which indeed fills the shelves of the Hawaiian Mission Children's Library, located in downtown Honolulu. Much of this material is quite readable, in spite of its pious intent. The little memoir of the Hawaiian lad called Henry Obookiah, who inspired the launching of the first shipload of missionaries that landed in the "Sandwich Islands" in 1820, is only the first of many volumes about this high-minded effort.

Foremost among the ministers of the Gospel who arrived in the Thaddeus in that critical year was the Reverend Hiram Bingham. His book about the twenty-one years he and his 
family spent in Hawaii is not limited to mission doings, but encompasses general observation of Hawaiian life during these and other years; it is history in which the historian had a quite active part.

Another member of the "First Company" of missionaries was Lucy Goodale Thurston, who spent the rest of her life in the islands and whose memoirs revive the excitements of that pioneer time. Another was Elisha Loomis, first printer in the North Pacific region, who with his wife labored seven years in God's vineyard-their story is told in Albertine Loomis's Grapes of Canaan, the best documentary novel of the early period. Another was Dr. Thomas Holman, Hawaii's first physician, who fills the opening chapters of Francis Halford's 9 Doctors and God, the story of the medical missionaries and other practitioners in the islands up to the twentieth century.

The most lively general account of the mission era is that by Bradford Smith, author of Yankees in Paradise: The New England Impact on Hawaii. He tells of the men and women who labored between 1820 and 1854, and of the problems they had to face. Prominent among the early workers were William Ellis, an energetic Englishman with experience in the South Pacific, and Charles S. Stewart, who helped to set up the first mission at Lahaina. Stewart's colleagues had bad as well as good experiences, such as suffering attacks by enraged seamen like "Mad Jack" Percival, commander of the Dolphin, first American warship to visit Honolulu, who resented restrictions upon visits aboard by complaisant Hawaiian maidens. The Dolphin story is told by First Lieutenant Hiram Paulding.

A medical missionary whose executive ability finally led him to leave the mission and embark upon the choppy waters of politics in the progressive kingdom was Dr. Gerrit P. Judd. He is the leading figure in Samuel Harrison's novel The White King, a historical narrative that departs only slightly from fact. This story is supplemented by the diary of his wife, Laura Fish Judd, who faithfully supported his moves and also bore him nine children-some of whose descendants, like those of the Thurstons, are still living in Hawaii today. 
The life of the islands in 1840 is graphically presented by the American traveler and artist Frederick A. Olmsted in Incidents of a Whaling Voyage. In the following year, the United States Exploring Expedition, the most ambitious scientific fleet hitherto sent out by any nation, arrived in Hawaii and began ransacking the islands for data of many sorts. Under the command of Charles Wilkes, a large party ascended snowcapped Mauna Loa and the workers spent three weeks in tents on the windy summit, making measurements at an elevation of almost fourteen thousand feet. The chapters on Hawaii in the voluminous report of the expedition made the world realize, almost for the first time, the wonders of the North Pacific archipelago that was not too far away from the western shore of the American continent.

Herman Melville, whose ramblings in the South Seas were to result in such novels as Typee, Omoo, and Moby Dick, was discharged from a whale ship at Lahaina in May 1843, and soon went to Honolulu, where, after serving as a pinsetter in a bowling alley, he signed an indenture as a clerk in a British general store. This attachment explains his defense, in an appendix to Typee, of the illegal annexation of the Hawaiian Islands in that year by Lord George Paulet, commander of the British frigate Carysfort. Melville was shocked by the saturnalia that followed the restoration of Hawaiian sovereignty by Admiral Richard Thomas on July 31. This short piece is the only factual writing by Melville about Hawaii, for he enlisted in an American vessel after only ten weeks; but elsewhere in Typee and in other books, such as Mardi, he does refer to his Hawaiian sojourn.

The "manifest destiny" of the United States to expand into the world's largest ocean brought travelers who, like George Washington Bates in 1853, toured the islands and recommended that a pending treaty between Kamehameha III and the United States should result in annexation of the kingdom.

The possibility that filibusters from California might achieve such an outcome by violence fills the opening chapter of $\mathrm{Ka}^{\prime} \mathrm{a}^{\prime} \mathrm{awa}$ : A Novel About Hawaii in the 1850s, by O. A. Bushnell. Dr. Bushnell, a professor of microbiology, is the foremost novelist born in Hawaii, and $K a^{\prime} a^{\prime} a w a$-the name 
of a village and valley on the North Shore of Oahu-is the third in his series of fine historical novels, beginning with one on the last days of Captain Cook.

The rise of the sugar industry in the islands, which replaced whaling as an economic mainstay, is told in the history of three prominent families, in Koamalu by Ethel M. Damon, an author who wrote other volumes dealing mainly with the later wave of missionaries and their descendants.

Richard Henry Dana, Jr. (1815-1882), Boston lawyer and author of Two Years Before the Mast, arrived in Honolulu in the autumn of 1859 on a British sailing ship that had rescued him and some two hundred others from a burning passenger vessel. He was made welcome by many residents of the city, including King Kamehameha IV and the court circle. After adventures on Oahu, Maui, and the Big Island, he was unable to find a ship that would permit him to continue his trip around the world, and he boarded a vessel that returned him to San Francisco. Aside from a chapter in the third volume of his Journal, however, Dana wrote little about Hawaii (see Appendix A).

During the middle of the past century began the fashion of considering the Hawaiian Islands a target for tourism-an industry that today brings in more income than the growing of sugar cane and pineapple put together. Among the first of these were Lady Jane Franklin, widow of the Arctic explorer, and her companion Sophia Cracroft, who left their impressions of the kingdom on the eve of the American Civil War, as told in The Victorian Visitors by Alfons L. Korn.

Just after that war, Samuel L. Clemens, a journalist who was beginning to use the pseudonym "Mark Twain," spent four months journeying around the islands and writing a series of travel letters for a California newspaper. Flavored with his typical wry humor, these accounts contain much serious observation on life in the kingdom, and were the basis for the speech that embarked Clemens on a highly successful career as a lecturer. The collected Letters from Hawaii, if published at that time, would have been Mark Twain's first book.

Other celebrated authors of travel books covered Hawaii 
during the next century. Among these were two British writers, Isabella Bird Bishop, who wrote The Hawaiian Archipelago, and Constance F. Gordon-Cumming, author of Fire Fountains.

Anthony Trollope, the prolific Victorian author, made two short visits to Honolulu, in October 1872 and in September 1875. On both occasions he was returning from visiting his son in Australia, and each time spent less than twenty-four hours in the city. About half of the nineteenth letter in his collection, The Tireless Traveler (Berkeley: University of California Press, 1941, ed. Bradford A. Booth), written after the second stop, is concerned with facts about the kingdom, but all could have been gleaned from two available guide books and from the history by Jarves.

Many admirers of Edward Bellamy, author of the utopian novel Looking Backward, are not aware that as a young man he made a visit to Hawaii. Seeking health, Edward and his ailing brother Frederick arrived from San Francisco around the first of March 1878. After his return to New England, Edward published in the magazine Good Company (5, 1880, pp. 8-15) a "frame story" called "A Tale of the South Pacific." Told by a native of "one of the remoter islands" to a party overtaken by night at the edge of the glowing Kilauea Volcano, the tale recounts the adventure of a white castaway who, by the use of ventriloquism, escapes his fate among South Sea cannibals. The author describes himself as "a mere tourist person, drawn to these remote regions by a desire dating from the perusal of Robinson Crusoe to behold a genuine Polynesian island, ere yet its primitive people should have succumbed in the effort to grapple with the philosophy of clothes and all that it implies."

A dreamy lotus-eater and romantic writer of sketches was Charles Warren Stoddard, who produced several collections of essays dealing with Hawaii and the South Seas. It was Stoddard who, in San Francisco, inspired tubercular Robert Louis Stevenson to spend his last years in the tropical zone of the Pacific.

Stevenson is one of the best-known authors to have spent some time in Hawaii, and his observations on the islands, in 
prose and verse, have been collected in a volume supplementing such fiction as "The Bottle Imp," "The Isle of Voices," and The Wrecker. His celebrated "Open Letter to the Reverend Dr. Hyde of Honolulu," a searing attack on a Protestant clergyman who made the mistake of slandering Father Damien, "martyr of Molokai," still offers fuel for spirited debate in Hawaii.

Political satire arose as a timely literary form around the middle 1880s, when the corruption of the reign of King Kalakaua became a target of scorn. A pamphlet appeared in 1886 entitled The Grand Duke of Gynbergdrinkenstein: a Burlesque in Three Acts (Honolulu: privately printed), which was "respectfully dedicated to the Public of the Duchy, Honolulu, H.I., 1886." In the rather heavy-handed ridicule, "Herr von Boss" is Claus Spreckels and "Nosbig"' is Walter Murray Gibson, an adviser to the king in several scandalous adventures. The play is attributed to Alatau T. Atkinson, editor of the Hawaiian Gazette and later minister of public instruction, in collaboration with Edward William Purvis. These two satirists presumably also worked together on some sprightly verse, The Gynberg Ballads (Honolulu: privately printed, n.d.), an illustrated pamphlet, printed in color. Purvis's brother claimed that Edward wrote all the ballads and did the illustrations. The humor barely conceals a warm indignation at the attempt by the court to sell the rights to import opium into the kingdom, and to presume to attain "primacy of the Pacific" through outfitting a guano-hauling windjammer as a Hawaiian gunboat to overawe island groups to the southward. Among those figuring in the $\mathrm{Bal}$ lads are Gibson (then foreign minister), Sam Parker, Attorney General Antone Rosa, Curtis Iaukea, "Marshal" Kaulukou, Captain George E. G. Jackson of the Kaimiloa, and Gibson's son-in-law, F. H. Hayselden.

At this same time appeared Vacuum, a Farce in Three Acts (Honolulu: privately printed, n.d.), in conventional playlet form, by an author who was later to head the government for an entire decade. This was Sanford Ballard Dole, future president of the republic of Hawaii and first territorial governor. Kalakaua is satirized under the title of "Skyhigh Em- 
peror of the Coral Reefs and Sand Banks of the Big Blue Sea." His cabinet includes the "Extravaganzies and Incompetents"' like Palaver (Gibson), Cockade, Calabash, and Picnic; Bananagan, Lord High Pipelighter to His Most Imperial Majesty; and Mango, First Kahili Bearer. It is likely that such propaganda had an effect upon the success of the Hawaiian League and the signing by Kalakaua of the concessive "Bayonet Constitution" of 1887.

The downfall of the monarchy and the rule by a provisional government, led by pro-annexation citizens, has been told by its leading figure, Lydia Liliuokalani, in Hawaii's Story by Hawaii's Queen, published in the year when the islands first lay under the Stars and Stripes. Both the revolution of 1893 and the ceremony of annexation in 1898 brought world attention to Hawaii, and a number of writers came to the islands in journalistic mood.

"Joaquin Miller," Western poet and poseur, visited Hawaii in the spring of 1895 , the period of the counterrevolution that failed to overthrow the republic. On duty as reporter, attired in leather leggings and a wide sombrero, he was found wandering around "the front" in Manoa Valley by a government officer. Miller had the effrontery to call upon President Dole, accompanied by his pregnant mistress, whom he introduced as the wife of his California plumber. Mrs. Dole discovered the deception and suggested that the pair leave the islands. Miller later published an article, "Kamehameha the Great" (Overland Monthly, series 2, 25, June 1895), which contains general remarks on Hawaiian life and people. He makes an interesting comment concerning Robert Louis Stevenson: "I am told that he often took steerage, although a very sick man; he wanted to see, to hear, and so he kept where he could learn something in the mighty university of humanity."

Other visitors who wrote about the islands during the revolutionary decade include Charles G. Nottage, Dr. Edward S. Goodhue, and Mary H. Krout.

The twentieth century ushered in an era of territorial rule. "They don't know what they've got!" exclaimed Jack London about the American people when he landed in the Terri- 
tory of Hawaii in 1907, on the first leg of a yachting cruise through the Pacific with his new wife Charmian. The California storyteller explored many corners of this offshore territory of the United States during a five-month stay, and the couple returned to Hawaii as their second home in 1915 and 1916. Two volumes of short stories and several other pieces by Jack have been collected as Stories of Hawaii. In her own right, Charmian is to be considered in the list, as author of such volumes as The Log of the "Snark" and Our Hawaii.

Among many other twentieth-century writers about Hawaii may be named Armine von Tempski, who was encouraged by Jack London to write such books as her popular autobiography Born in Paradise. Earl Derr Biggers, the creator of the celestial detective Charlie Chan, wrote The House Without a Key as a result of a visit to Honolulu. University teachers like Ruth Eleanor McKee, O. A. Bushnell, and Marjorie Sinclair have enriched the growing shelf of solid fiction with Hawaiian settings. The impact of the "blitz" on Pearl Harbor in 1941 elicited not only factual books like Blake Clarke's Remember Pearl Harbor! and Walter Lord's Day of Infamy but warime fiction like James Jones' From Here to Eternity and The Pistol. Since those years of conflict, the most notable novel about the islands-a giant panorama covering the millions of years from the emergence of the archipelago from the depths of the ocean to an imaginary election campaign in 1954-is James A. Michener's pageant of Pacific assimilation, simply titled Hawaii.

Aside from translations of native chants and songs, few outstanding examples of poetry in English have come from Hawaii. The inhabitants have been less occupied in voicing high dreams in verse than in assimilating newcomers from other lands and in building a sturdy economy. Then, too, the lushness of the surroundings may lead to a similar unpruned luxuriance in outpourings inspired by swaying palm fronds and hula skirts.

Visiting poets have voiced their feelings about Hawaii. Both Stevenson and Stoddard produced verses with island settings. Rupert Brooke, the young English poet, during a 
short stay in 1913 wrote one of his finest sonnets, "Waikiki." World War II brought to the islands, staging area for the Pacific conflict, a million men that included several young poets, among them William Meredith, Louis O. Coxe, and Donald Stauffer. The best poet to grow up in Hawaii is undoubtedly Genevieve Taggard, but she departed at the age of twenty and wrote little verse about the tropics. More recent names come to mind-Don Blanding, Lloyd Stone, and Clifford Gessler. At present, a number of competent poets center around the University of Hawaii-among them Phyllis Thompson, John Logan, and John Unterecker. Not all of these, however, have chosen the Hawaiian setting for their verse. One may hope that their example may inspire some of the polyracial young people of the community to produce, in the not too distant future, the fine poetry that Hawaii deserves.

The drama is an even more difficult genre to create in a community that has still not agreed upon its fundamental standards. Many plays are produced in the islands, but few by local playwrights. Jean Charlot-an artist who writes in both English and Hawaiian-Aldyth Morris, and John Kneubuhl, among others, have had plays produced. The lively department of drama at the University of Hawaii may be expected to elicit playable scripts, in English or in other languages.

The literature of Hawaii, when compared with that of larger regions, may not be outstanding. Yet few authors anywhere are Shakespeares or Miltons. If the authors of Hawaiian writings are to be classed as "minor," one should remember the remarks of Newton Arvin in his book Longfellow: "Americans are notoriously obsessed with the question of status, and to say that a writer is a minor writer, to many American readers, is as if one were to say that he is negligible. This is not true, or it is much less true, in Europe, where steadily, through the most seismic upheavals of taste, writers of the second or even the third order continue to be edited, to be published, and to be read. They are often, too, the objects of thoughtful critical discussion, and the general consciousness is appreciably enriched as a result. By an understandable 
paradox, we are much more 'democratic' in our receptiveness, and much less catholic. Our memories, too, are shorter, and once a writer has receded from the foreground of our attention, he runs the risk of being forgotten irretrievably, especially if he can be disposed of as a minor writer." Good books about Hawaii are not so prevalent that we can afford to discard any of them.

This book is a companion to my previous volume, Pacific Islands Literature: One Hundred Basic Books (Honolulu: University Press of Hawaii, 1971), and follows the same general scheme of presenting good reading material from a Pacific area. I have selected fifty authors of books about Hawaii to review at more or less length, and in the appendixes have annotated three times that many. I have not attempted to set up a strict canon to limit the pleasures of individual discovery, but have merely tried to demonstrate the rich variety of literary offerings in English from the fiftieth state. It is quite possible that some of the titles in the appendixes should have been included among the fifty, and others demoted. I hope I have not overlooked anyone's favorite classic. I have not defined "literature" for my purpose so rigidly as to omit from consideration anything quite readable. Although all the books deal with the general setting of the Hawaiian Islands, my test is whether the book chosen would be read for its charm or power, regardless of setting.

All the books-except for a few reference works listed in Appendix C-are considered, then, to offer pleasurable perusal. Deliberately omitted are textbooks, scientific works, guide books, special volumes such as almanacs and cookbooks, and items for children. Works mentioned are in the English language. Some, of course, are translations. One more qualified than I might well write a comparable work on books about Hawaii in tongues other than English. For example, persons of Japanese ancestry in Hawaii, I am told, have written in their language several hundred books, including histories, biographies, reminiscences, essays, novels, and poems.

My purpose, then, is to share with other readers some re- 
sults of my haunting of the Hawaiian Collection in the University of Hawaii Library for more than thirty years, and to make known my opinions of selected volumes that have literary value. My choices are influenced by half a lifetime of research spent on the literature that has come from the Pacific region. During this time I have edited ten volumes of anthologies of such literature, five of them in collaboration with my colleague Carl Stroven. It was he who originated, forty years ago, the course in "Literature of the Pacific" that has been given at least once each year since that time at the University of Hawaii-a unique course which I had the pleasure of offering for a decade and which is now given by several others in Honolulu. My appreciation of the aid and suggestions coming from the staff of the University Library, as well as the responses of students and other readers, is warmly acknowledged here.

Users of this book should be aware of some of the methods followed. The fifty main reviews deal with the outstanding work of each chosen author. Information is also given about other writings on Hawaii by these authors, with some pertinent biographical data. Books on similar subjects by other writers are sometimes mentioned.

The arrangement by number is chronological, based on the date of the first episode in any series of events covered. The first items are general works, or deal with prehistory and folklore; then, with the journals of James Cook, begins the period of documentary history, followed by accounts by other voyagers and adventurers, coming down to the period of statehood. Reading these reviews in this order might serve as a rough outline of the history of Hawaii as well as of the history of the literature of Hawaii.

The length of a review is not necessarily an indication of a work's importance. The title numbers are used for crossreferences in the reviews; the account of William Hyde Rice, for example, naturally directs the reader to a later volume giving the history of his family. The index of authors covers all mentions of a writer, not only in this preface and in the main reviews but in the appendixes. In each entry, first editions are given. An American edition precedes others, even 
though a British edition might have antedated it. The names of publishers, although requiring much research, should be of value in tracing editions. Later editions, especially paperback reprints, are frequently mentioned, but no attempt has been made to indicate all transitory republication.

My choices have not been concerned with the present availability of copies. One additional value of this book, it is hoped, is that it might encourage the growing tendency to reprint-perhaps with scholarly introductions-a number of the fine works that have not yet been recognized by those publishers who have discovered the demand for new editions of what might be termed Hawaiian classics.

If you will read most or all of my fifty basic books-which would, I believe, form a good start to a bookshelf of Hawaiian literature in any library-you will qualify, certainly, as an authority when someone asks: "What should I read about Hawaii?" 